\title{
Goiter Prevalence in School Children in Three Districts of Jammu Region
}

Rajiv Kumar Gupta, M.D., Aruna Kumari Verma, M.D., Devinder Singh Jamwal, M.D., Vijay Mengi, M.D. Postgraduate Department of Community Medicine, GMC Jammu (J\&K), India

\section{A B S T R A C T}

BACKGROUND: IDD (lodine Deficiency Disorders) is still a major public health problem in J\&K as in other parts of country despite measures taken to combat it. Repeated surveys are only means to monitor the situation.

OBJECTIVE: To study the present prevalence of goiter in various districts of Jammu province.

METHODS: Using EPI 30 cluster methodology, 10800 school children (aged, 6-12 years) were selected from three randomly chosen districts of Jammu province. Subjects were clinically examined and graded for goiter as per joint WHO/UNICEF/ ICCIDD recommendations

RESULTS: The goitre prevalence in three districts was observed to be $19.84 \%$ with a highest prevalence of $26.75 \%$ in Samba district $(p=0.0001)$. Understandably the prevalence of goitre in age group of 6-9 years was lower than that in 9-12 age group. ( $(p=0.005)$

CONCLUSIONS: Total goiter prevalence rate remains to be at an unacceptable high rate. Preventive public health measures need to be augmented in area along with strengthening of monitoring and surveillance of IDD. JMS 2012;15(1):28-31.

Key Words: Goiter, Prevalence, Jammu, iodine deficiency, IDD

Recent studies at national and regional level have shown that the prevalence of goiter in the region has declined to more than half from previous levels. ${ }^{1,2}$ Yet, it constitutes a major public health problem in Jammu Province with total goiter prevalence rate of 10-11.9\%. ${ }^{3,4}$ This is higher than the Kashmir Province as reported by Imtiaz A Bhat et al and Pandit Mohammad et al. ${ }^{3}$ Monitoring and evaluation of the impact of programmes to control Iodine deficiency disorder (IDD) are crucial in order to ensure that interventions are both effective and safe. Current recommendations are that countries conduct a national survey on the status of IDD in populations every 3-5

\section{Correspondence:}

Dr. Rajiv K. Gupta

Assisstant Professor

PG Department of Community Medicine, GMC Jammu

E-Mail: rajivguptagmc@rediffmail.com years. ${ }^{6}$ In 2008, 4 more districts were carved in Jammu Province hence the study was taken up by the authors to know the post iodization scenario in Jammu region.

\section{Methods}

Multistage cross sectional study was done. In 1st stage; 3 Districts were chosen randomly out of 10 districts of Jammu province. In second stage, zone wise educational institutes were identified from the list procured from chief educational officer giving due representation to urban and rural areas. Thus, 7-10 coeducational schools were selected randomly from various zones. Using EPI 30 cluster sampling methodology 120 students with 20 students in each 6 age categories were selected. ${ }^{7}$ The required sample size of 3600 students was calculated considering minimum prevalence of goiter at $10 \%$ with $10 \%$ allowable error (using formula $4 \mathrm{pq} / \mathrm{L} 2$ ). All the 
children were examined by a pre trained team of postgraduates and grading of goiter was done as per criteria recommended by joint WHO/UNICEF/IAs study was conducted under aegis of our department; urinary excretion of iodine was not done because of non availability of resources in Biochemistry Department of College. The results were compiled and statistical analysis was done by using Epi info.

\section{Results}

10800 school children in age group of 6-12 years were screened for goiter in all, with 3600 school children in each 3 selected districts of Jammu province.

Total goiter prevalence rate was highest in Samba district (26.75) followed by $26.25 \%$ in Udhampur District and $21.7 \%$ in Jammu District. This interdistrict variation in prevalence of goiter was also observed to be statistically significant $(p=.0001)$ and same has been shown in Table 1.

This table also shows the severity of goiter. Grade I goiter was more prevalent in Samba district $(21.25 \%)$ as compared to grade II goiter which was higher in Udhampur district this was was compared it was observed that there was no statistically significant difference between 2 sexes in both age categories and same has been shown in table 2 .

$25.46 \%(n=1317)$ children had goiter in rural areas where as $24.38 \%(n=1317)$ had goiter in urban areas. When

TABLE 2. Age and Sex wise Goiter prevalence in three districts of Jammu province

\begin{tabular}{cccccccc}
$\begin{array}{l}\text { Age in } \\
\text { years }\end{array}$ & Sex & $\begin{array}{c}\text { No. of } \\
\text { children } \\
\text { examined }\end{array}$ & G0 & G1 & G2 & $\begin{array}{c}\text { Total goiter } \\
\text { Prevalence (\%) } \\
\text { G1 + G2p }\end{array}$ & $\begin{array}{c}p \\
\text { value }\end{array}$ \\
\hline $6-9$ & M & 3237 & 2517 & 596 & 124 & $\begin{array}{c}720 \\
(22.24 \%)\end{array}$ & 0.683 \\
& F & 2161 & 1693 & 400 & 68 & $\begin{array}{c}468 \\
(21.66 \%)\end{array}$ & \\
$9-12$ & M & 3198 & 2317 & 706 & 175 & $\begin{array}{c}881 \\
(27.54 \%)\end{array}$ & 0.966 \\
& F & 2204 & 1581 & 503 & 120 & $\begin{array}{c}623 \\
(28.26 \%)\end{array}$ & \\
\hline
\end{tabular}

Table 1. Prevalence of Goiter in Three Districts of Jammu Province

\begin{tabular}{|c|c|c|c|c|c|c|}
\hline \multirow[t]{2}{*}{ District } & \multirow[t]{2}{*}{ Sex } & \multirow{2}{*}{$\begin{array}{l}\text { No. of students } \\
\text { examined }\end{array}$} & \multirow{2}{*}{$\begin{array}{c}\text { No.of students } \\
\text { with goiter } \\
n(\%)\end{array}$} & \multicolumn{2}{|c|}{ Grade of goiter } & \multirow{2}{*}{$\begin{array}{l}\text { Total Goiter Rate } \\
\text { (TGR) }\end{array}$} \\
\hline & & & & $\begin{array}{c}\text { Grade I } \\
n(\%)\end{array}$ & $\begin{array}{c}\text { Grade II } \\
n(\%)\end{array}$ & \\
\hline \multirow[t]{3}{*}{ Jammu } & M & 2168 & 491 (22.64) & & & \\
\hline & $\mathrm{F}$ & 1432 & $293(20.46)$ & 723 (20.08) & $61(1.69)$ & $21.7 \%$ \\
\hline & $\mathrm{T}$ & 3600 & 784 (21.78) & & & \\
\hline \multirow[t]{3}{*}{ Udhampur } & M & 2256 & $520(23.04)$ & & & \\
\hline & $\mathrm{F}$ & 1344 & 425 (31.62) & 171 (19.92) & $228(6.33)$ & $26.25 \%$ \\
\hline & $\mathrm{T}$ & 3600 & $945(26.25)$ & & & \\
\hline \multirow[t]{3}{*}{ Samba } & M & 2146 & 590 (27.49) & & & \\
\hline & $\mathrm{F}$ & 1454 & $373(25.65)$ & 765 (21.25) & $198(5.5)$ & $26.75 \%$ \\
\hline & $\mathrm{T}$ & 3600 & $963(26.75)$ & & & \\
\hline
\end{tabular}

$P$ value (boys vs. Girls): $0.211,0.0001,0.351$ for Jammu, Udhampur, Samba, respectively

also observed to be statistically highly significant at $p$ value of .00001 . It was also observed that $24.87 \%$ of screened males had goiter as compared to $24.99 \%$ of females but this gender difference was not statistically significant. When this data was further analysed for variation of goiter prevalence in either of sex and spatial distribution, it was observed that $31.62 \%$ of females in Udhampur district had goiter as compared to $23.04 \%$ of males, this was also found to be statistically highly significant with p value of.0001. (Table 2)

According to age, $27.84 \%(n=1504)$ of children had goiter in age group of $9-12$ years as compared to only $22.0 \%$ $(n=1188)$ students who had goiter in age group of 6-9 years. This was also observed to be statistically highly significant at $p$ value $<.005\left(\chi^{2} 42.9 \mathrm{df}=1\right)$. But when age and sex prevalence analysed for severity of goiter 3.5\% $(n=192)$ had grade II goiter in urban areas as compared to $5.46 \%(n=295)$ children from rural areas. This was also observed to be statistically significant at $p$ value of .00004 and same has been depicted in Table 3 .

\section{Discussion}

Present study was based on only clinical examination of 10800 children between age of 6-12 years taking baseline prevalence of goiter at $10 \%$ with allowable error of $10 \%$. To take care of confounding because of pubertal goiter, 6-12 years age group children were taken. Total goiter prevalence came out to be $24.9 \%$ as compared to $11.98 \%$ as reported by Imtiaz A Bhat $e t$ al. ${ }^{5}$ This is almost double than previous report and quite high in contrast to goiter prevalence from Srinagar region which was 
TABLE 3. Distribution of Goiter in Urban and Rural children (Age 6-12yrs) in three Districts of Jammu

\begin{tabular}{lcccc} 
& \multicolumn{4}{c}{ Presence of goiter and Severity } \\
\cline { 2 - 4 } Spatial & $\begin{array}{c}\text { Goiter } \\
\text { Distribution } \\
\text { G0 }\end{array}$ & $\begin{array}{c}\text { Absent } \\
\text { Urban }\end{array}$ & $\begin{array}{c}\text { Goiter } \\
\text { Present }\end{array}$ & $\begin{array}{c}\text { Total goiter } \\
\text { Prevalence (\%) } \\
\text { G1 }\end{array}$ \\
\cline { 2 - 4 } & 4083 & 1125 & 192 & $24.38 \%$ \\
Rural & $(75.62 \%)$ & $(20.83 \%)$ & $(3.55 \%)$ & \\
& 4025 & 1080 & 295 & $25.46 \%$ \\
& $(74.53 \%)$ & $(20.00 \%)$ & $(5.46 \%)$ & \\
Combined & 8108 & 2205 & 487 & $24.92 \%$ \\
& $(75.07 \%)$ & $(20.41 \%)$ & $(4.50 \%)$ & \\
\hline
\end{tabular}

reported to be at $5.57 \%$ by Rafiq $\mathrm{M}$ in $2006 .{ }^{2}$ However, these figures have almost halved from previously reported prevalence of $45.2 \%$ in 19951 . Our study conforms to Marwaha R.K. et al ${ }^{9}$ who also reported total goiter rate of $23 \%$ in 14762 school children aged 6-18 years from different states and Union territories. High prevalence of goiter has also been reported by other authors. ${ }^{10}$ When district wise data was analysed, Jammu district showed higher prevalence $(21.7 \%)$ as compared to earlier study done by by Imtiaz A Bhat et al. ${ }^{5}$ This difference may be because of small sample size and different sample unit in their study as compared to ours. Moreover district Samba which was erstwhile part of Jammu district had highest total goiter prevalence than all other districts in the study group which supports our results.

Overall, there was no gender difference in goiter prevalence rate but in Udhampur district $31.62 \%$ of females had goiter as compared to $23.04 \%$ of males. Similar finding were reported by Masoodi MA et al in their study done in to 2003-04 who observed that total goiter rate was $17 \%$ in girls and $13.67 \%$ in boys in the age group of 6-12 years. ${ }^{11}$ Similar results have been observed by other authors in their studies. ${ }^{12,13,14}$ Pandit Mohamed Iqbal ${ }^{3}$ also reported statistically significant higher prevalence of goiter amongst females of Jammu region $(16.1 \%$ vs $11 \%)$ as compared to males respectively.

In our study, age and prevalence of goiter was significantly associated as $27.84 \%$ of children had goiter in age group of 9-12 years as compared to only $22.0 \%$ of children in 6-9 years age category. This conforms to the study done by Imitiaz A Bhat et $a l^{5}$ who reported that $12.8 \%$ of children aged 9-12 years had goiter as compared to $10.6 \%$ children in 6-8 years age category.

Children from rural areas showed higher but statistically non significant goiter prevalence as compared to children from urban areas (25.46\% vs $24.38 \%$ respectively) But Grade II goiter was more common in rural areas as compared to urban areas and this was also significantly associated.

Limitation of the study was that since we did not assess the adequacy of Iodine in salt or measure urinary excretion of iodine in surveyed population; we cannot say with authenticity that in our area the high prevalence of goiter is due to programme inefficiency or because of other micronutrient deficiencies, auto immunity or higher presence of thiocynates as suggested by other authors in their studies. ${ }^{15,16,17}$ According to NFHS-3 (2005-06) out of 100 samples of edible salt which were tested for iodine content in Jammu region; 9.5\% of samples were non iodized; $14.7 \%$ of samples had inadequate iodine content $(<15 \mathrm{ppm})$ while $75.8 \%$ of samples had adequate iodine content $(15+\mathrm{ppm}){ }^{18}$ Bhat IA et al also observed that $98.1 \%$ of salt samples were adequately iodized yet; in Jammu region Median urinary iodine excretion was 96.5 $\mathrm{ug} / \mathrm{L}$ while in Kupwara district (Kashmir Division) it was 300 $\mathrm{ug} / \mathrm{L}^{5}$.

\section{Conclusion}

Total goiter prevalence in studied population is much higher (24.09\%) than previously reported study (12\%) in 2008. This calls for immediate attention of authorities to augment the goiter control measures for sustainability of NIDDCP and increase awareness as regards to IDD in the general public.

\section{References}

1. Zargar AH, Shah JA, Mir MM, Laway BA, Masoodi: SR, Shah NA. Prevalence of goiter in school children in Kashmir Valley. IndiaAMJClin Nutri 1995;65(5):1020-21.

2. Rafiq M, Shahnaz, Masoodi MA, Bilquees S, Qureshi KA, Jan R. Prevalence of goiter in school children aged 612 years in district Budgam (Kashmir division). JKPractitioner 2006;13(3):166-68.

3. Pandit IM, Bhat IA, Mudasir S, Mir AA. Prevalence of Iodine deficiency Disorders in Jammu \& Kashmir state, India. Journal of Medical Sciences 2008;11(2): 58-88.

4. Kapil U. Successful efforts towards Elimination of Iodine deficiency disorders in India. Indian Journal of Community Medicine 2010;35(4): 455-68.

5. Bhat IA, Pandit IM, Mudassar S. Study on prevalence of Iodine Deficiency Disorder and Salt Consumption Patterns in Jammu Region. Indian Journal of Community Medicine 2008;33(1):11-14.

6. Sustaining the Elimination of Iodine Deficiency Disorders (Resolution WHA 60.21) Progress report by the secretariat to the Sixty third world Assembly. Jagriti; 2010; VIII(2).

7. Report of joint $\mathrm{WHO} / \mathrm{UNICEF} / \mathrm{ICCIDD}$ consultation on indicators for assessing IDD and their control programmes. 1992 World Health Organisation, Geneva; 1992 WHO\NDH $\backslash 99.4$.

8. Assessment of Iodine deficiency and monitoring their Elimination A guide for programme managers; Second Edi; ICCIDD/UNICEF/WHO2001:3-4. 
9. Marwaha RK, Tandan N, Gupta N, Karak AK, Verma K, Kochipillai N. Residual goiter in the post iodination phase, iodine status, thiocyanate exposure and auto immunity. Clinical Endocrinol 2001;59:672-81.

10. Kapil U, Sohal KS, Sharma TD, Tandon M, Pathak P. Assessment of Iodine Deficiency Disorders using the 30 cluster Approach in District Kangra, Himachal Pradesh, India.Journal of Tropical Paedriatics 2000;(46):264-66.

11. Masoodi MA, Rafiq M (unpublished data). Project report of goiter prevalence study in Srinagar District 2003-4 submitted to Assistant Director Planning H\&ME Civil Secretariat J\&K.

12. Sahoo T, Sarani NC, Satpathy DM, Behorar TR. Prevalence of goiter in 6-12 years old children of Kandhamal district in Orissa. Indian J Community Med 2005;30:51-52

13. Biswas AB, Chakraboraty I, Das DK. IDD among school age children of Birbhum west Bengal. Current Science 2004, 87: 7880 .
14. Singh MB, Marwal R, Lakshminarayan J. Assessment of Iodine Deficiency Disorder in School Age Children in Jodhpur District of Rajasthan J Hum E Col 2010;2:79-83.

15. Brauer VF, Schweizer U, Kohrle J, Paschke R. Selenrium and goiter prevalence and borderline iodine sufficiency. EurJ Endocrinol 2006;155:807-12.

16. Hess SY, Zimmermann MB, Adou P, Torresani T, Hurrell RF. Treatment of iron deficiency in Goitrous children improves the efficacy of iodized salt in Cote $\mathrm{d}^{\prime}$ Ivoire. AmJ Clin Metr 2002;75.743-48.

17. Das S, Bhansali A, Dutta P, Aggarwal A, Bansal MP, Garg Dinesh, Ravikiran M Walia R, Upreti V, Ramakrishnan S, Sachdeva N, Bhadada SK. Persistence of goiter in the post-iodization phase: micronutrient deficiency or thyroid autoimmunity. Indian J Med Res 2011;133:103-9.

18. International Institute for Population Sciences (IIPS) and ORC Macro National Famiily Health Survey (NFHS3) 2005-6. Mumbai IIPS; New Delhi: Ajanta Offset and Packagings Limited 2006. 260-90. 